\title{
PERENCANAAN ANGGARAN BIAYA PEKERJAAN KAYU STYLE BALI BERDASARKAN ANALISA HARGA SATUAN LAPANGAN
}

\author{
Ni Kadek Sri Ebtha Yuni ${ }^{1}$, I Nyoman Suardika ${ }^{2}$ \\ ${ }^{1}$ Jurusan Teknik Sipil, Politeknik Negeri Bali, Badung, Bali, 80361 \\ E-mail: ebthayuni@pnb.ac.id \\ ${ }^{2} J u r u s a n$ Teknik Sipil, Politeknik Negeri Bali, Badung, Bali, 80361
}

\begin{abstract}
ABSTRAK
Kekhasan pekerjaan kayu style Bali berdampak pada tidak ada standar Analisa Harga Satuan pada SNI atau PU, sehingga diperlukan adanya analisis harga satuan pekerjaan khususnya untuk pekerjaan kayu style Bali. Penelitian ini dilakukan pada pengrajin di Kabupaten Gianyar. Penelitian dilakukan dengan cara menghitung produktivitas tenaga kerja, kebutuhan material dan alat, survei harga upah dan material. Dalam menyusun RAB dengan 3 alternatif yaitu kombinasi saka, lambang dan pintu style Bali dan melakukan wawancara untuk memperoleh data identifikasi faktor yang mempengaruhi harga pekerjaan kayu style Bali. Pekerjaan yang ditinjau adalah (1) saka ukir, (2) saka polos, (3) lambang gembol, (4) lambang sari, (5) lambang polos, (6) pintu ukir. Berdasarkan hasil analisis diperoleh Harga pekerjaan saka ukir dengan panjang $3 \mathrm{~m}$ adalah Rp 4.815.046/ unit dan saka polos Rp 3.288.025/ unit. Harga lambang gambol per m adalah Rp 3.944.438/ m', Lambang sari Rp 2.500.688/ m' dan lambang polos Rp 1.554.813/ m'. Harga pintu kayu ukir ukuran 800 x 2000 mm Rp 29.002.400/ unit. Adapun spesifikasi dari harga di atas adalah menggunakan material kayu jati kualitas I, finishing politur. Biaya Overhead \& Profit $5 \%$ diasumsikan sama dengan analisa pada SNI yaitu 5\%. Dari 3 alternatif yang ditentukan diperoleh RAB alternatif 1 Rp 94,806,962, alternatif 2 Rp 60,501,304, alternatif 3 Rp Rp 77,770,712. Adapun faktor yang teridentifikasi mempengaruhi harga pekerjaan style Bali, yaitu umur pekerja, pendidikan, modal usaha, jumlah tenaga kerja, teknologi, pengalaman kerja, produktivitas, pendapatan pengrajin, keahlian, tingkat kesulitan, jenis ukiran, proses produksi.
\end{abstract}

Kata Kunci: pekerjaan kayu style Bali, analisa harga satuan, produktivitas, RAB

ABSTRACT

Currently, the work unit price for Balinese style woodwork is not yet available, so it is necessary to analyze the unit price of the work, especially for Balinese style woodwork. This research was conducted on craftsmen in Gianyar. The research by calculating labor productivity, material and equipment requirements, surveying wage and material prices, compiling a budget plan with three alternatives and conducting interviews to obtain data on the identification of factors that affect the price of Balinese style woodwork. The jobs reviewed are (1) carving saka, (2) plain saka, (3) gembol symbols, (4) sari symbols, (5) plain symbols, (6) carving doors. Based on the results of the analysis, it is found that the price of carving work with a length of $3 m$ is Rp. 4,815,046 and Rp. 3,288,025. The price of the gambol symbol per $m$ is IDR 3,944,438, - The sari symbol is IDR 2,500,688 and the plain symbol is IDR 1,554,813. The price of carved wooden doors measuring $800 \times 2000 \mathrm{~mm}$ is $\mathrm{Rp}$. 29,002,400. The specifications of the price above are to use good quality teak wood material, finishing politur. Overhead Cost \& Profit 5\% is the same as the analysis on SNI, which is 5\%. Of the 3 alternatives that are determined, it is obtained alternative $R A B 1$ Rp. 94,806,962, alternative $2 \mathrm{Rp}$. 60,501,304, alternative $3 \mathrm{Rp}$. 77,770,712. The factors identified affect the price of Balinese style work, namely worker age, education, working capital, number of workers, technology, work experience, productivity, craftsmen's income, expertise, level of difficulty, type of carving, production process.

Keywords: woodwork Balinese style, unit price analysis, productivity, RAB

\section{PENDAHULUAN}

Penggunaan material kayu dan bambu pada konstruksi bangunan tradisional Bali akan mempengaruhi struktur, yang berdampak pada wujud bangunan [1]. Perencanaan estimasi biaya saling berkaitan dengan analisa harga satuan, yang berarti pekerjaan yang menyangkut pengkajian biaya kegiatan-kegiatan terdahulu yang akan digunakan selanjutnya sebagai bahan dalam menyusun perkiraan biaya [2]. Harga satuan pekerjaan di setiap daerah berbeda-beda, baik harga bahan maupun upah pekerja berbeda sehingga dalam perhitungan dan perencanaan anggaran biaya suatu bangunan/ proyek, harus berpedoman pada harga satuan bahan, upah tenaga kerja di pasaran dan lokasi di proyek [3]. Penyusunan analisa harga satuan diawali dengan menentukan besarnya produktivitas tenaga kerja, dan kebutuhan sumber daya bahan, alat yang diperlukan.

Besarnya produktivitas pekerja menunjukkan kemampuan tenaga kerja dalam menyelesaikan kuantitas pekerjaan. Setiap pekerja memiliki produktivitas yang berbeda-beda [10]. Hal tersebut dipengaruhi adanya faktor - faktor produktivitas antara 
lain meliputi: pengalaman, pengetahuan, usia, dan sebagainya. Pengalaman kerja berpengaruh positif dan signifikan terhadap produktivitas pengrajin dengan nilai $\beta$ yaitu 0,621 [4]. Secara parsial teknologi tidak berpengaruh terhadap produksi Industri kerajinan ukiran kayu, sementara modal dan tenaga kerja berpengaruh positif dan signifikan terhadap produksi Industri kerajinan ukiran kayu di Kecamatan Ubud Kabupaten Gianyar [5].

Pembuatan bangunan style Bali pada umumnya ditawarkan secara borongan atau lumpsum. Karena kondisi ini, sulit bagi pemilik proyek dalam memperkirakan anggaran biaya yang diperlukan dalam proses pembuatan bangunan dengan material kayu ukir style Bali, dengan menggunakan beberapa jenis saka, lambang, dan pintu. Berdasarkan permasalahan inilah perlu dilakukan analisis untuk menentukan harga satuan pekerjaan kayu style Bali. Dari harga satuan bisa dilakukan perhitungan rencana anggaran biaya bangunan yang menggunakan kayu style Bali. Pada penelitian ini juga bertujuan untuk menghitung analisa harga satuan, menghitung RAB dengan 3 alternatif, mengidentifikasi faktor yang mempengaruhi harga pekerjaan style Bali. Adapun pekerjaan yang menjadi lingkup penelitian adalah (1) saka ukir, (2) saka polos, (3) lambang gembol, (4) lambang sari, (5) lambang polos, (6) pintu ukir.

\section{TINJAUAN PUSTAKA}

Analisis harga satuan pekerjaan adalah suatu cara perhitungan harga satuan pekerjaan konstruksi yang dijabarkan dalam perkalian kebutuhan bahan bangunan, upah kerja, dan peralatan dengan harga bahan bangunan, standar pengupahan pekerja dan harga sewa / beli peralatan untuk menyelesaikan per satuan pekerjaan konstruksi. Analisis harga satuan pekerjaan ini dipengaruhi oleh angka koefisien yang menunjukkan nilai satuan bahan/material, nilai satuan alat, dan nilai satuan upah tenaga kerja ataupun satuan pekerjaan yang dapat digunakan sebagai acuan/panduan untuk merencanakan atau mengendalikan biaya suatu pekerjaan. Koefisien tenaga kerja ditentukan untuk mengetahui jumlah tenaga kerja dan waktu yang digunakan untuk menyelesaikan satu item pekerjaan dengan volume tertentu [6], dapat dihitung dengan persamaan berikut:

$$
\text { Koefisien Man Hour }=\frac{\text { Jumlah Tenaga Kerja (orang) } \mathrm{x} \text { Durasi Pekerjaan }(\mathrm{jam})}{\text { Volume Pekerjaan' } / \text { jam }}
$$

Upah tenaga kerja yang dibayarkan dihitung dalam satuan hari, maka perlu diketahui koefisien man day dari tenaga kerja. Dapat dihitung dengan persamaan berikut.

$$
\text { Koefisien Man Day }=\frac{\text { Koefisien Man Hour }}{\text { Jumlah Jam Kerja dalam } 1 \text { Hari }}
$$

Analisis bahan, ialah menghitung volume masing-masing bahan, serta besarnya biaya yang dibutuhkan. Sedangkan yang dimaksud dengan analisis upah pekerjaan ialah, menghitung banyaknya tenaga yang diperlukan, serta besarnya biaya yang dibutuhkan untuk pekerjaan tersebut. Kebutuhan bahan dan upah tenaga kerja dapat dicari menggunakan rumus sebagai berikut:

1. Bahan = Volume Pekerjaan $\mathrm{x}$ Koefisien Analisis bahan

2. Tenaga Kerja = Volume Pekerjaan $\mathrm{x}$ Koefisien Analisis tenaga kerja

Untuk menentukan biaya suatu unit pekerjaan sebagai bagian dari kegiatan proyek, dilakukan estimasi biaya [7]. Perkiraan biaya atau estimasi biaya adalah seni memperkirakan (the art of approximating) kemungkinan jumlah biaya yang diperlukan untuk suatu kegiatan yang didasarkan atas informasi yang tersedia pada waktu itu. Dalam prosesnya, tiap-tiap kategori estimasi harus secara hati-hati dipersiapkan dari tingkat estimasi konseptual sampai pada estimasi detail untuk memperoleh keakuratan estimasi biaya konstruksi.

Ukiran Bali terdiri dari beberapa jenis yaitu [11] :

1. Pepatran, yang merupakan jenis ukiran yang bermotifkan dari dedaunan (Patra) dan memiliki hiasan bermotif bungabungaan. Misalnya Patra Sari ditempatkan pada bidang yang sempit seperti tiang-tiang dan blandar, patra lainnya adalah patra pid-pid, patra samblung, patra pal, patra ganggong, patra sulur dan lain-lain. Jenis ragam hias ini berwujud gubahangubahan keindahan hiasan dalam patern-patern yang juga disebut patra. Ide dasar pepatran banyak diambil dari bentukbentuk keindahan flora.

2. Kekarangan, yang merupakan bentuk ukiran yang bermotifkan dari bentuk-bentuk makhluk binatang yang biasanya ditonjolkan pada bagian kepala. Menampilkan suatu bentuk hiasan dengan suatu karangan yang berusaha mendekati bentuk-bentuk flora yang ada dengan penekanan bagian-bagian keindahan.

3. Keketusan, mengambil bagian terpenting dari suatu tumbuh-tumbuhan yang dipolakan berulang dengan pengolahan untuk memperindah penonjolannya. Keketusan dalam ragam hias tradisional sangat banyak jenisnya, seperti: keketusan wangga yang menggambarkan bunga-bunga besar yang mekar dari jenis tanaman yang berdaun lebar

Bagian badan bangunan terdiri dari beberapa bagian yang dapat dijelaskan pada gambar potongan struktur berikut: 


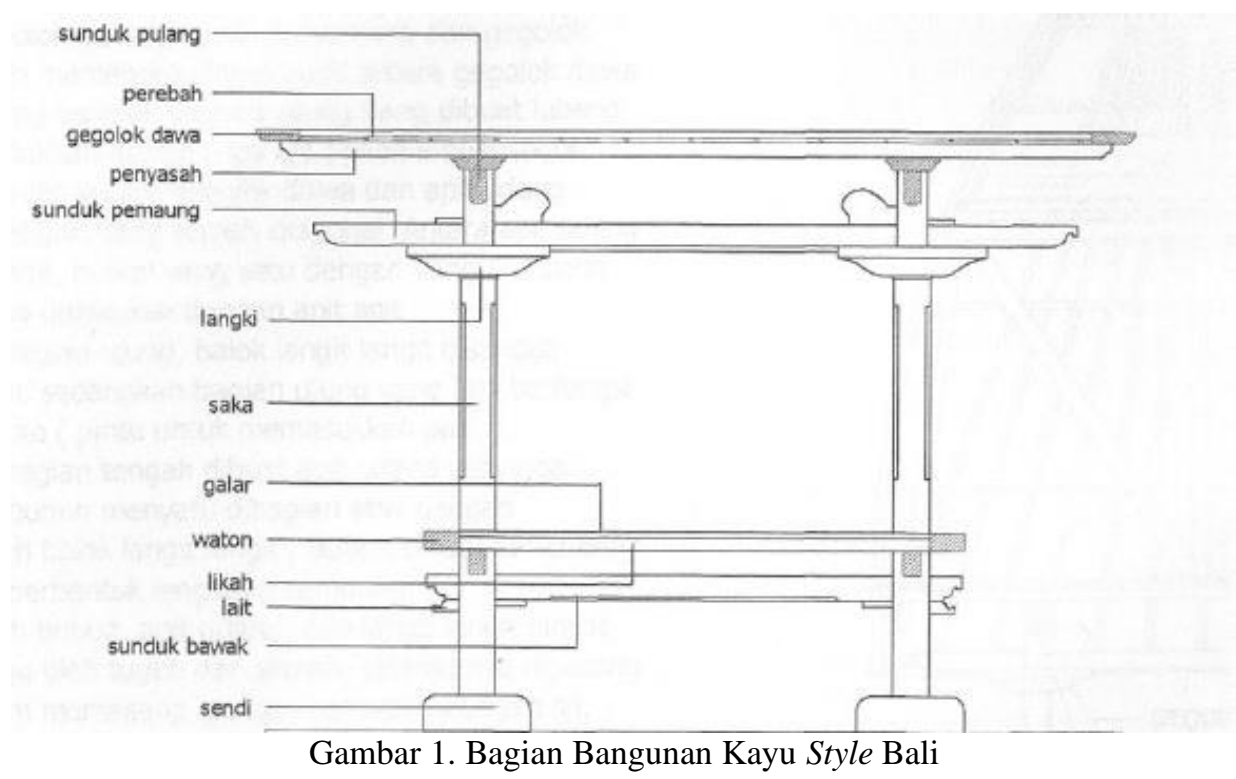

\section{METODELOGI PENELITIAN}

Penelitian ini dilakukan pada pekerjaan kayu style Bali yang ada di Kabupaten Gianyar. Metode pengolahan data yang digunakan yaitu deskriptif kuantitatif dengan pengamatan langsung di lapangan dan melakukan wawancara. Data wawancara yang dikumpulkan akan menghasilkan yaitu : karakteristik responden berdasarkan umur, pendidikan, pengalaman kerja, wilayah dan analisis harga satuan pekerjaan kayu style Bali. Hasil observasi adalah berupa jenis pekerjaan, volume pekerjaan yang dikerjakan, waktu pelaksanaan, jumlah tenaga kerja. Pekerjaan kayu style Bali yang dianalisis adalah (1) pekerjaan saka kayu style Bali, (2) pekerjaan lambang kayu style Bali, (3) pekerjaan pintu kayu style Bali. Secara singkat, tahapan-tahapan dalam melaksanakan penelitian ini adalah sebagai berikut:

1. Mengumpulkan data sekunder berdasarkan penelitian terdahulu.

2. Mengumpulkan data primer yang diperoleh langsung dari lapangan dengan metode observasi dan wawancara.

Data hasil wawancara diperoleh data harga bahan dan upah pekerjaan, identifikasi faktor yang mempengaruhi harga pekerjaan. Observasi memperoleh data berupa: (a) volume pekerjaan, (b) waktu pekerjaan, (c) jumlah tenaga kerja, (d) jenis pekerjaan.

3. Melakukan analisis, dengan langkah-langkah analisis data sebagai berikut :

a. Pengumpulan data melalui observasi lapangan. Data yang dikumpulkan berupa: jenis pekerjaan yang dikerjakan, jumlah tenaga kerja yang bekerja setiap harinya, volume pekerjaan yang diselesaikan dalam sehari, peralatan yang digunakan, kebutuhan material yang diperlukan.

b. Pengolahan data, yaitu:

(1) Menghitung produktivitas tenaga kerja dalam satu hari

(2) Menghitung koefisien tenaga kerja dalam satuan orang hari $(\mathrm{OH})$

(3) Menghitung kebutuhan material kayu yang digunakan untuk memperoleh koefisien material.

(4) Melakukan survei harga material dan upah tenaga kerja.

(5) Menyusun analisa harga satuan pekerjaan.

(6) Menghitung RAB dengan 3 alternatif.

c. Menentukan identifikasi faktor yang mempengaruhi biaya pekerjaan kayu style Bali berdasarkan hasil wawancara.

Data sekunder dalam penelitian ini diperoleh dari kajian terhadap jurnal, studi literatur, laporan-laporan yang telah dilaksanakan. Mengumpulkan data primer yang diperoleh langsung dari lapangan dengan metode wawancara. Data hasil wawancara yang di lakukan oleh peneliti di lapangan berupa harga bahan dan upah pekerjaan, identifikasi faktor yang mempengaruhi harga pekerjaan. Data inilah yang nantinya akan digunakan untuk menghitung besarnya produktivitas dan koefisien upah kerja dan bahan. Data-data yang digunakan adalah berupa: (1) volume pekerjaan, (2) waktu pekerjaan, (3) jumlah tenaga kerja, (4) jenis pekerjaan, (5) harga satuan bahan dan upah.

\section{PEMBAHASAN}

Struktur bangunan tradisonal Bali yang ditinjau dalam penelitian ini adalah sebagai berikut : (1) saka ukir, (2) saka polos, (3) lambang gembol, (4) lambang sari, (5) lambang polos, (6) pintu ukir. 


\subsection{Menghitung Kebutuhan Material}

Untuk menghitung analisa harga satuan pekerjaan diawali dengan menghitung kebutuhan bahan. Bahan yang digunakan adalah sesuai persyaratan yang diinginkan yaitu mengenai jenis, kuantitas, maupun komposisi suatu bahan. Berikut merupakan perhitungan kebutuhan bahan untuk pekerjaan kayu style Bali. Berikut kebutuhan material kayu:

Tabel 1. Kebutuhan Material Kayu Jati

\begin{tabular}{clccc}
\hline \multirow{2}{*}{ No } & \multirow{2}{*}{\begin{tabular}{c} 
Uraian \\
\cline { 3 - 4 }
\end{tabular}} & $\begin{array}{c}\text { Ukuran Kotor } \\
(\mathrm{mm})\end{array}$ & $\begin{array}{c}\text { Banyak } \\
(\mathrm{Btg})\end{array}$ & Volume $\left(\mathrm{m}^{3}\right)$ \\
\hline 1 & Saka & $120 \times 120 \times 4000$ & 1 & 0,057 \\
\hline 2 & Lambang & $110 \times 220 \times 1000$ & 1 & 0,024 \\
\hline 3 & Kusen & $60 \times 120 \times 2000$ & 2 & 0,028 \\
\hline & & $60 \times 120 \times 800$ & 1 & 0,005 \\
\hline 4 & Daun pintu & $20 \times 800 \times 2000$ & 1 & 0,032
\end{tabular}

Hasil perhitungan kebutuhan material berdasarkan data ukuran kayu masing-masing pekerjaan dan jumlahnya, maka diperoleh kebutuhan material kayu jati untuk pekerjaan saka adalah $0,057 \mathrm{~m}^{3}$, lambang $0,024 \mathrm{~m}^{3}$, kusen termasuk daun pintu $0,066 \mathrm{~m}^{3}$.

\subsection{Menghitung Produktivitas Tenaga Kerja}

Produktivitas adalah perbandingan antara volume yang dikerjakan dengan jumlah waktu yang dibutuhkan untuk mengerjakan pekerjaan tersebut. Berikut adalah produktivitas tenaga kerja pada pekerjaan saka ukir dan polos, lambang gembol, lambang sari, dan lambang polos, pintu ukir style Bali:

Tabel 2. Produktivitas Pekerjaan Saka, Lambang, Pintu Ukir

\begin{tabular}{|c|c|c|c|c|c|c|c|}
\hline Pekerjaan & $\begin{array}{c}\text { Observasi } \\
\text { No. }\end{array}$ & $\begin{array}{l}\text { Output } \\
\text { (m') }\end{array}$ & $\begin{array}{c}\text { ST (standard } \\
\text { time) } \\
\text { (menit) }\end{array}$ & $\begin{array}{l}\text { Produktivitas } \\
\text { (m/hari) }\end{array}$ & $\begin{array}{l}\text { Tenaga } \\
\text { kerja } \\
\text { (Orang) }\end{array}$ & $\begin{array}{l}\text { Koefisien } \\
\text { (org/jam) }\end{array}$ & $\begin{array}{l}\text { Koefisien } \\
\quad(\mathrm{OH})\end{array}$ \\
\hline \multirow[t]{5}{*}{ Saka Ukir } & 1 & 0,063 & 60 & 0,500 & 1 & 16,000 & 2,000 \\
\hline & 2 & 0,100 & 60 & 0,800 & 1 & 10,000 & 1,250 \\
\hline & 3 & 0,138 & 60 & 1,100 & 1 & 7,300 & 0,910 \\
\hline & 4 & 0,075 & 60 & 0,600 & 1 & 13,300 & 1,670 \\
\hline & Rata-Rata & 0,094 & 60,000 & 0,750 & 1,000 & 11,652 & 5,83 \\
\hline \multirow[t]{3}{*}{ Saka Polos } & 1 & 0,150 & 60 & 1,200 & 1 & 6,700 & 0,830 \\
\hline & 2 & 0,225 & 60 & 1,800 & 1 & 4,400 & 0,560 \\
\hline & Rata-Rata & & & 3,000 & & & 1,390 \\
\hline \multirow{4}{*}{$\begin{array}{l}\text { Lambang } \\
\text { Gembol }\end{array}$} & 1 & 0,038 & 60 & 0,300 & 1 & 26,700 & 3,330 \\
\hline & 2 & 0,038 & 60 & 0,300 & 1 & 26,700 & 3,330 \\
\hline & 3 & 0,050 & 60 & 0,400 & 1 & 20,000 & 2,500 \\
\hline & Rata-Rata & & & 1,000 & & & 9,170 \\
\hline \multirow[t]{3}{*}{ Lambang Sari } & 1 & 0,075 & 60 & 0,600 & 1 & 13,300 & 1,670 \\
\hline & 2 & 0,050 & 60 & 0,400 & 1 & 20,000 & 2,500 \\
\hline & Rata-Rata & & & 1,000 & & & 4,170 \\
\hline \multirow[t]{2}{*}{ Lambang Polos } & 1 & 1,000 & 60 & 1,000 & 1 & 8,000 & 1,000 \\
\hline & Rata-Rata & & & 1,000 & & & 1,000 \\
\hline \multirow[t]{4}{*}{ Pintu Ukir } & 1 & 0,006 & 60 & 0,200 & 2 & 80,000 & 10,000 \\
\hline & 2 & 0,006 & 60 & 0,150 & 1 & 53,300 & 6,670 \\
\hline & 3 & 0,013 & 60 & 0,150 & 1 & 53,300 & 6,670 \\
\hline & 4 & 0,010 & 60 & 0,100 & 1 & 80,000 & 10,000 \\
\hline
\end{tabular}




\begin{tabular}{cccccccc}
\hline Pekerjaan & $\begin{array}{c}\text { Observasi } \\
\text { No. }\end{array}$ & $\begin{array}{c}\text { Output } \\
\left(\mathrm{m}^{\prime}\right)\end{array}$ & $\begin{array}{c}\text { ST (standard } \\
\text { time }) \\
(\text { menit })\end{array}$ & $\begin{array}{c}\text { Produktivitas } \\
(\mathrm{m} / \text { hari })\end{array}$ & $\begin{array}{c}\text { Tenaga } \\
\text { kerja } \\
(\text { Orang) }\end{array}$ & $\begin{array}{c}\text { Koefisien } \\
(\text { org/jam })\end{array}$ & $\begin{array}{c}\text { Koefisien } \\
(\mathrm{OH})\end{array}$ \\
\cline { 2 - 7 } & 0,005 & 60 & 0,200 & 2 & 80,000 & 10,000 \\
6 & 0,013 & 60 & 0,150 & 1 & 53,300 & 6,670 \\
7 & 0,010 & 60 & 0,200 & 2 & 80,000 & 10,000 \\
8 & 0,006 & 60 & 0,100 & 1 & 80,000 & 10,000 \\
\hline 9 & 0,009 & 60 & 0,200 & 2 & 80,000 & 10,000 \\
10 & 0,011 & 60 & 0,150 & 1 & 53,300 & 6,670 \\
\hline
\end{tabular}

Berdasarkan tabel 2, rata-rata produktivitas pekerja untuk menyelesaikan saka ukir dengan panjang 3 m adalah dibutuhkan tenaga kerja 5,83 orang hari $(\mathrm{OH})$, untuk menyelesaikan saka polos dengan panjang $3 \mathrm{~m}$ dibutuhkan tenaga kerja 1,39 orang hari $(\mathrm{OH})$, Untuk menyelesaikan lambang gembol per 1 meter dibutuhkan tenaga kerja 9,17 orang hari (OH), untuk menyelesaikan lambang sari per 1 meter dibutuhkan tenaga kerja 4,17 orang hari $(\mathrm{OH})$, untuk menyelesaikan lambang polos per 1 meter dibutuhkan tenaga kerja 1,00 orang hari $(\mathrm{OH})$, Untuk 1 unit pekerjaan pintu ukir dibutuhkan tenaga kerja 86,67 orang hari $(\mathrm{OH})$.

\subsection{Analisa Harga Satuan Pekerjaan Kayu Style Bali}

Berdasarkan hasil dari kebutuhan material kayu dan produktivitas tenaga kerja dapat dihitung analisa harga satuan pekerjaan, Spesifikasi pekerjaan kayu style Bali adalah menggunakan material kayu jati kualitas paling bagus, proses pabrikasi yaitu pemotongan dan serut menggunakan mesin statis, proses pengupakan atau membentuk kayu menggunakan peralatan manual, Finising menggunakan politur yang diawali dengan proses pengamplasan, jenis ukiran yang digunakan adalah ukiran standar umum, Tenaga kerja menggunakan pekerja lokal Bali asal Gianyar, Adapun analisa hasil perhitungan adalah sebagai berikut:

Tabel 3. Rekap Analisa Harga Satuan Pekerjaan Saka, Lambang, Pintu Ukir

\begin{tabular}{|c|c|c|c|c|c|c|c|}
\hline No & Uraian & $\begin{array}{l}\text { Saka Ukir } \\
\quad \text { (Rp) }\end{array}$ & $\begin{array}{l}\text { Saka Polos } \\
\quad \text { (Rp) }\end{array}$ & $\begin{array}{c}\text { Lambang } \\
\text { Gembol (Rp) }\end{array}$ & $\begin{array}{l}\text { Lambang } \\
\text { Sari (Rp) }\end{array}$ & $\begin{array}{l}\text { Lambang } \\
\text { polos (Rp) }\end{array}$ & $\begin{array}{l}\text { Pintu Ukir } \\
\text { (Rp) }\end{array}$ \\
\hline \multirow[t]{6}{*}{$\mathbf{A}$} & BAHAN & & & & & & \\
\hline & Kayu Jati & $2.030 .400,000$ & $2.030 .400,000$ & $853.050,000$ & $853.050,000$ & $853.050,000$ & $2.291 .250,000$ \\
\hline & Amplas & $5.000,000$ & $2.500,000$ & $1.250,000$ & $1.250,000$ & $1.250,000$ & $2.500,000$ \\
\hline & Cat dasar & $8.075,000$ & $8.075,000$ & $8.075,000$ & $8.075,000$ & $8.075,000$ & $14.250,000$ \\
\hline & Politur & $75.000,000$ & $37.500,000$ & $75.000,000$ & $75.000,000$ & $75.000,000$ & $150.000,000$ \\
\hline & Jumlah & $2.118 .475,000$ & $2.078 .475,000$ & $937.375,000$ & $937.375,000$ & $937.375,000$ & $2.458 .000,000$ \\
\hline \multirow[t]{5}{*}{ B } & TENAGA KER & & & & & & \\
\hline & Tukang ukir & $1.602 .083,330$ & $277.777,780$ & $2.520 .833,330$ & 1.145 .833 .330 & $275.000,000$ & $23.833 .333,33$ \\
\hline & Tukang kupak & $300.000,000$ & $300.000,000$ & $100.000,000$ & $100.000,000$ & $100.000,000$ & $480.000,000$ \\
\hline & $\begin{array}{l}\text { Tukang } \\
\text { finishing }\end{array}$ & $450.000,000$ & $360.000,000$ & $150.000,000$ & $150.000,000$ & $120.000,000$ & $720.000,000$ \\
\hline & Jumlah & $2.352 .083,330$ & $937.777,780$ & $2.770 .833,330$ & $1.395 .833,330$ & $495.000,000$ & $25.033 .333,33$ \\
\hline \multirow[t]{3}{*}{$\mathbf{C}$} & PERALATAN & & & & & & \\
\hline & Pabrikasi & $115.200,000$ & $115.200,000$ & $48.400,000$ & $48.400,000$ & $48.400,000$ & $130.000,000$ \\
\hline & Jumlah & $115.200,000$ & $115.200,000$ & $48.400,000$ & $48.400,000$ & $48.400,000$ & $130.000,000$ \\
\hline $\mathrm{D}$ & $\begin{array}{l}\text { Jumlah } \\
(A+B+C)\end{array}$ & $4.585 .758,330$ & $3.131 .452,780$ & $3.756 .608,330$ & $2.381 .608,330$ & 1.480 .7750 & $27.621 .333,33$ \\
\hline $\mathrm{E}$ & $\begin{array}{l}\text { Overhead \& } \\
\text { Profit }\end{array}$ & $229.287,920$ & $156.572,640$ & $187.830,420$ & $119.080,420$ & $74.038,750$ & $1.381 .066,670$ \\
\hline $\mathrm{F}$ & $\begin{array}{l}\text { Harga Satuan } \\
\text { Pekerjaan } \\
(\mathrm{D}+\mathrm{E})\end{array}$ & $4.815 .046,250$ & $3.288 .025,420$ & $3.944 .438,750$ & $2.500 .688,750$ & $1.554 .813,750$ & $29.002 .400,00$ \\
\hline
\end{tabular}

Berdasarkan tabel di atas, harga satuan pekerjaan saka per 1 unit dengan panjang 3 m yaitu saka ukir Rp 4.815.046,250 dan saka polos 3.288.025,420 Analisa harga satuan lambang per 1 meter yaitu lambang gembol Rp 3.944.438.750 lambang sari 
Rp 2.500.688,750 dan lambang polos Rp 1.554.813,750 Analisa harga satuan untuk 1 unit pintu ukir ukuran 800 x 2000 mm yaitu Rp 29.002.400,000.

\subsection{Rencana Anggara Biaya Pekerjaan Kayu Style Bali}

Adapun alternatif rencana anggaran biaya $(\mathrm{RAB})$ pekerjaan kayu style Bali adalah sebagai berikut:

Tabel 3. Rekap Analisa Harga Satuan Pekerjaan Saka. Lambang. Pintu Ukir

\begin{tabular}{clllcc}
\hline No. & \multicolumn{1}{c}{ Alternatif 1 } & \multicolumn{1}{c}{ Alternatif 2 } & Alternatif 3 & Volume & Satuan \\
\hline 1 & Saka Ukir & Saka Polos & Saka Ukir & 4 & bh \\
\hline 2 & Lambang gembol & Lambang polos & Lambang sari & 11,8 & $\mathrm{~m}$ \\
\hline 3 & Pintu Ukir & Pintu ukir & Pintu Ukir & 1 & Unit \\
\hline 4 & Finishing politure & Finishing politure & Finishing politure & & \\
\hline 5 & Material kayu jati & Material kayu jati & Material kayu jati & & \\
\hline 6 & Jenis ukiran menengah & $\begin{array}{l}\text { Jenis ukiran } \\
\text { menengah }\end{array}$ & $\begin{array}{l}\text { Jenis ukiran } \\
\text { menengah }\end{array}$ & & \\
\hline
\end{tabular}

Masing-masing alternatif dibuat anggaran biaya berdasarkan volume. dan analisa harga satuan yang telah diperoleh. Berikut adalah rencana anggaran biaya masing-masing alternatif:

Tabel 4. Rencana Anggaran Biaya Alternatif 1

\begin{tabular}{llcccc}
\hline No. & Alternatif 1 & Volume & Satuan & $\begin{array}{c}\text { Harga } \\
\text { Satuan (Rp) }\end{array}$ & Total (Rp) \\
\hline 1 & Saka Ukir & 4 & buah & 4.815 .046 & 19.260 .185 \\
\hline 2 & Lambang gembol & 11,8 & $\mathrm{~m}$ & 3.944 .439 & 46.544 .377 \\
\hline 3 & Pintu Ukir & 1 & unit & 29.002 .400 & 29.002 .400 \\
\hline & Total & & & & $\mathbf{9 4 . 8 0 6 . 9 6 2}$ \\
\hline
\end{tabular}

Berdasarkan alternatif 1 dengan menggunakan material kayu jati. saka ukir. lambang gambol. pintu ukir. finishing politure. dan jenis ukiran menengah dengan volume seperti pada tabel. diperoleh rencana anggaran biaya sebesar Rp 94.806.962.

Tabel 5. Rencana Anggaran Biaya Alternatif 2

\begin{tabular}{llcccl}
\hline No. & Alternatif 2 & Volume & Satuan & $\begin{array}{c}\text { Harga Satuan } \\
\text { (Rp) }\end{array}$ & Total (Rp) \\
\hline 1 & Saka Polos & 4 & buah & 3.288 .025 & 13.152 .102 \\
\hline 2 & Lambang polos & 11,8 & $\mathrm{~m}$ & 1.554 .814 & 18.346 .802 \\
\hline 3 & Pintu ukir & 1 & unit & 29.002 .400 & 29.002 .400 \\
\hline & Total & & & & $\mathbf{6 0 . 5 0 1 . 3 0 4}$ \\
\hline
\end{tabular}

Berdasarkan alternatif 2 dengan menggunakan material kayu jati. saka polos. lambang polos. pintu ukir. finishing politure. dan jenis ukiran menengah dengan volume seperti pada tabel. diperoleh rencana anggaran biaya sebesar Rp 60.501.304.

Tabel 6. Rencana Anggaran Biaya Alternatif 3

\begin{tabular}{llccrl}
\hline No. & Alternatif 3 & Volume & Satuan & $\begin{array}{c}\text { Harga Satuan } \\
(\text { Rp) }\end{array}$ & Total (Rp) \\
\hline 1 & Saka ukir & 4 & buah & 4.815 .046 & 19.260 .185 \\
\hline 2 & Lambang sari & 11,8 & $\mathrm{~m}$ & 2.500 .689 & 29.508 .127 \\
\hline 3 & Pintu ukir & 1 & unit & 29.002 .400 & 29.002 .400 \\
\hline & Total & & & & $\mathbf{7 7 . 7 7 0 . 7 1 2}$ \\
\hline
\end{tabular}

Berdasarkan alternatif 3 dengan menggunakan material kayu jati, saka ukir, lambang sari, pintu ukir, finishing politure, dan jenis ukiran menengah dengan volume seperti pada tabel, diperoleh rencana anggaran biaya sebesar Rp 77.770.712. 


\subsection{Identifikasi Faktor yang Mempengaruhi Harga Pekerjaan Kayu Style Bali}

Untuk memperoleh identifikasi faktor yang mempengaruhi harga pekerjaan kayu style Bali diperoleh melalui wawancara dan brainstorming dengan 10 responden yang sudah terpilih. Tidak hanya berupa wawancara dan brainstorming. identifikasi faktor yang berpengaruh juga berdasarkan penelitian terdahulu. Adapun identifikasi faktor yang mempengaruhi harga pekerjaan style Bali adalah seperti tabel berikut:

Tabel 7. Identifikasi Faktor yang Mempengaruhi Harga Pekerjaan Kayu Style Bali

\begin{tabular}{|c|c|c|}
\hline No & Identifikasi & Sumber Identifikasi \\
\hline 1 & Umur pekerja & [5]. wawancara \\
\hline 2 & Tingkat pendidikan & [5]. wawancara \\
\hline 3 & Modal usaha & [4]. [5]. [8]. wawancara \\
\hline 4 & Jumlah tenaga kerja & [4]. [5]. [8]. wawancara \\
\hline 5 & Teknologi & [4]. [5]. [8]. wawancara \\
\hline 6 & Pengalaman kerja & [4]. wawancara \\
\hline 7 & Produktivitas Pengrajin & {$[4]$} \\
\hline 8 & Pendapatan Pengrajin & [4]. [8] \\
\hline 9 & Keahlian & wawancara \\
\hline 10 & Tingkat kesulitan pekerjaan & wawancara \\
\hline 11 & Jenis ukiran & wawancara \\
\hline 12 & Proses produksi (pemesanan atau proses) & [9] \\
\hline 13 & Harga material & wawancara \\
\hline
\end{tabular}

Berdasarkan tabel di atas. diperoleh bahwa harga pekerjaan kayu style Bali dipengaruhi oleh 13 hal berdasarkan penelitian terdahulu dan wawancara/ brainstorming.

\section{SIMPULAN DAN SARAN}

\subsection{Simpulan}

Hasil perencanaan anggaran biaya pada penelitian ini adalah:

1. Harga pekerjaan kayu style Bali yang dianalisis adalah pekerjaan saka ukir, saka polos, lambang gambol, lambang sari, lambang polos dan pintu ukir. Masing-masing jenis pekerjaan memiliki analisa harga satuan berbeda-beda. Harga pekerjaan saka ukir dengan panjang $3 \mathrm{~m}$ adalah $\mathrm{Rp}$ 4.815.046 dan saka polos Rp 3.288.025. Harga lambang gambol per $\mathrm{m}$ adalah $\mathrm{Rp}$ 3.944.438.- Lambang sari Rp 2.500.688 dan lambang polos Rp 1.554.813. Harga pintu kayu ukir ukuran 800 x 2000 mm Rp 29.002.400. Adapun spesifikasi dari harga di atas adalah menggunakan material kayu jati kualitas I, finishing politur. Biaya Overhead \& Profit $5 \%$ diasumsikan sama dengan analisa pada SNI yaitu 5\%.

2. Rencana Anggaran Biaya (RAB) dibuat dengan 3 alternatif berbeda sesuai dengan jenis pekerjaan yang dianalisis. Alternatif 1 dengan menggunakan material kayu jati. saka ukir. lambang gambol. pintu ukir. finishing politure. dan jenis ukiran menengah diperoleh rencana anggaran biaya sebesar Rp 94.806.962. Alternatif 2 dengan menggunakan material kayu jati. saka polos. lambang polos. pintu ukir. finishing politure. dan jenis ukiran menengah diperoleh rencana anggaran biaya sebesar Rp 60.501.304. Alternatif 3 dengan menggunakan material kayu jati. saka ukir. lambang sari. pintu ukir. finishing politure. dan jenis ukiran menengah diperoleh rencana anggaran biaya sebesar Rp 77.770.712.

3. Berdasarkan hasil wawancara dan penelitian terdahulu. adapun faktor yang teridentifikasi mempengaruhi harga pekerjaan style Bali ada 13 faktor. yaitu umur pekerja. tingkat pendidikan. modal usaha. jumlah tenaga kerja. teknologi. pengalaman kerja. produktivitas pengrajin. pendapatan pengrajin. keahlian. tingkat kesulitan pekerjaan. jenis ukiran. proses produksi (pemesanan atau proses).

\subsection{Saran}

Saran yang dapat peneliti berikan mengenai penelitian ini adalah sebagai berikut :

1. Untuk penelitian selanjutnya disarankan memperbanyak mengambil tinjauan pekerjaan kayu style bali. mengambil data pada beberapa tempat pengrajin kayu style Bali. dan diperluas pada Kabupaten lainnya.

2. Penelitian ini bisa dilanjutkan untuk pekerjaan style Bali lainnya yang materialnya seperti batu temple dan batu ukir. 


\section{ACKNOWLEDGMENT}

Pada kesempatan ini penulis mengucapkan terima kasih yang sebesar-besarnya kepada keluarga yang selalu memberikan semangat dan motivasi dalam melakukan penelitian. Ucapan terima kasih juga penulis sampaikan kepada tim peneliti yang meluangkan waktu untuk survei pencarian data

\section{REFERENCES}

[1] Primadewi. SPN. 2015. Struktur \& Konstruksi Bangunan Tradisional Bale Pengaman di Desa Bayung Gede. Kabupaten Bangli. Universitas Mahasaraswati. Denpasar.

[2] Sariani. N L A. 2011. Estimasi Biaya Konstruksi Gedungdengan Metode Cost Significant Model (Studi Kasus Proyek Konstruksi Gedung Pemerintah di Kabupaten Jembrana). Universitas Udayana. Denpasar.

[3] Ibrahim. H. Bachtiar. 1993. Rencana Dan Estimate Real Of Cost. Cetakan ke-2. Bumi Aksara. Jakarta

[4] Muliani. S.M.N. 2015. Pengaruh Pengalaman Kerja Terhadap Produktivitas Pengerajin untuk Menunjang Pendapatan Pengrajin Ukiran Kayu. E-Jurnal Ekonomi Pembangunan Universitas Udayana. Vol. 5. No. 5. Denpasar.

[5] Yuniartini. S.P.N. 2013. Pengaruh Modal. Tenaga Kerja. dan Teknologi Terhadap Produksi Industri Kerajinan Ukiran Kayu di Kecamatan Ubud. E-Jurnal Ekonomi Pembangunan Universitas Udayana. Vol. 2. No. 2. Denpasar.

[6] Messah. Y A. dkk. 2013. Analisa Indeks Biaya Untuk Pekerjaan Beton Bertulang Dengan Menggunakan Metode Sni 7394-2008 Dan Lapangan (Studi Kasus Pada Proyek Pembangunan Asrama Stikes Chmk Tahap III).

[7] Husen. Abrar. 2009. Manajemen Proyek. Andi. Yogyakarta

[8] Mahayasa. I.B.A. 2017. Pengaruh Modal. Teknologi. dan Tenaga Kerja Terhadap Produksi dan Pendapatan Usaha Kerajinan Ukiran Kayu di Kecamatan Tembuku Kabupaten. E-Jurnal Ekonomi Pembangunan Universitas Udayana. Vol. 6. No. 8. Denpasar.

[9] Wijayanti. K.D. 2019. Analisis Perbandingan Penggunaan Job Order Coasting Method dan Process Coasting Method Untuk Meningkatkan Akurasi Laba Usaha (Studi Kasus pada Stile Bali Ukir Desa Jinengdalem. Kecamatan Buleleng. Kabupaten Buleleng). JIMAT (Jurnal Ilmiah Mahasiswa Akuntansi) Universitas Pendidikan Ganesha. Vol: 10 No: 1. Buleleng.

[10] Ukkas.I. 2017. Faktor-Faktor yang Mempengaruhi Produktivitas Tenaga Kerja Industri Kecil Kota Palopo. Journal of Islamic Education Management. Vol.2. No.2

[11] Yoga.W.B.S. dan Eskak.E. 2015. Ukiran Bali dalam Kreasi Gitar Elektrik (Balinese Carving in Electric Guitar Creation). Dinamika Kerajinan dan Batik. Vol.32. No.2. 